\title{
Development of a biotinylated DNA probe for detection and identification of infectious hematopoietic necrosis virus
}

\author{
R. E. Deering ${ }^{1}$, C. K. Arakawa ${ }^{2}$, K.H. Oshima ${ }^{2}$, P.J. O'Hara ${ }^{3}$, M. L. Landolt ${ }^{1}$, \\ J. R. Winton ${ }^{2, *}$ \\ ${ }^{1}$ University of Washington, School of Fisheries, WH-10, Seattle, Washington 98195, USA \\ ${ }^{2}$ U.S. Fish and Wildlife Service, National Fisheries Research Center, Bldg. 204, Naval Station, Seattle, Washington 98115, USA \\ ${ }^{3}$ ZymoGenetics Inc., 4225 Roosevelt Way NE, Seattle, Washington 98105, USA
}

\begin{abstract}
A nonradioactive DNA probe assay was developed to detect and identify infectious hematopoietic necrosis virus (IHNV) using a dot blot format. The probe, a synthetic DNA oligonucleotide labeled enzymatically with biotin, hybridized specifically with nucleocapsid mRNA extracted from infected cells early in the virus replication cycle. A rapid, guanidinium thiocyanate based, RNA extraction method using RNAzol B and microcentrifuge tubes efficiently produced high quality RNA from 3 commonly used fish cell lines, CHSE-214, CHH-1, and EPC. The probe reacted with 6 diverse isolates of IHNV, but did not react with 2 related rhabdoviruses of fish, viral hemorrhagic septicemia virus and Hirame rhabdovirus. The biotinylated probe was sensitive, detecting picogram levels of target mRNA. Detection and identification of IHNV required $2 \mathrm{~d}$ when cells were inoculated at multiplicities of infection (MOI) greater than 2. Five days were necessary to detect and identify IHNV in cells inoculated at a MOI of 0.0002 .
\end{abstract}

\section{INTRODUCTION}

Infectious hematopoietic necrosis virus (IHNV), a rhabdovirus, is the causative agent of infectious hematopoietic necrosis (IHN), an important viral disease affecting juvenile sockeye salmon Oncorhynchus nerka, chinook salmon $O$. tshawytscha, and rainbow trout $O$. mykiss raised in hatcheries (Wolf 1988). The virus is enzootic among many stocks of salmonid fish on the west coast of North America from northern California to Alaska (Grischkowsky \& Amend 1976) and epizootics have been reported among feral populations (Williams \& Amend 1976, Traxler 1986). The appearance of IHNV among fish in Japan (Sano et al. 1977), Taiwan (Chen et al. 1985), Italy (Bovo et al. 1987), and France (Hattenberger-Baudouy et al. 1989) may be due to the importation of eggs taken from infected adults in the USA. Both the virus and the disease have been studied extensively, and have been comprehensively reviewed by Wolf (1988).

\footnotetext{
- Addressee for reprint requests
}

Because viral diseases remain largely untreatable, efforts to control the losses caused by IHNV have relied upon avoidance through the examination of broodstock and destruction of infected fish and eggs. Techniques for the isolation and diagnosis of viral pathogens of fish, including IHNV, have traditionally involved virus isolation in cell culture and confirmation by serum neutralization tests (Amos 1985), a process taking 14 d or more (Hsu \& Leong 1985). Hence, an important priority for IHNV research has been the development of methods for rapid screening and specific diagnosis. While rapid serological tests have been developed (Dixon \& Hill 1984, McAllister \& Schill 1986, Way \& Dixon 1988, LaPatra et al. 1989), these tests generally lack sensitivity for detection of IHNV in tissues and fluids without initial amplification of the virus in cell culture.

Nucleic acid probes offer the possibility of a rapid, sensitive, and specific test for IHNV. This technology has been used for detection and diagnosis of human and nonhuman viral pathogens (Richman \& Wahl 1986. Landegren et al. 1988, Tenover 1988) and is rapid and more sensitive than serological techniques such as the enzyme-linked immunosorbent assay (ELISA) (Kurstak 
et al. 1986). The probe, a labeled strand of DNA, will spontaneously recognize the target sequence (an opposite strand of DNA or RNA) in a reaction that can be manipulated for specificity by adjusting the temperature and salt concentration (Bryan et al. 1986). This paper describes the application of nucleic acid technology to the detection of IHNV using a synthetic oligonucleotide probe labeled with biotin.

\section{MATERIALS AND METHODS}

Cells and viruses used. Epithelioma papulosum cyprini (EPC; Fijan et al. 1983) cells, chinook salmon embryo (CHSE-214: ATCC 1681) and chum salmon heart (CHH-1; ATCC 1680) cells (Lannan et al. 1984) were maintained in Eagle's minimum essential medium (Flow Labs, McLean, VA, USA) supplemented with $10 \%$ fetal bovine serum (Gibco, Grand Island, NY, USA), 2 mM L-glutamine (Gibco), 0.3\% tryptose phosphate (Difco, Detroit, MI, USA), $100 \mathrm{IU} \mathrm{ml}^{-1}$ penicillin, $100 \mu \mathrm{g} \mathrm{ml}^{-1}$ streptomycin and $100 \mu \mathrm{g} \mathrm{ml} \mathrm{m}^{-1}$ gentamicin sulfate (U.S. Biochem. Corp., Cleveland, OH, USA) at $\mathrm{pH}$ 7.5. The CHSE-214 and $\mathrm{CHH}-1$ cells were grown at $18^{\circ} \mathrm{C}$, the EPC cells at $25^{\circ} \mathrm{C}$

Six isolates of IHNV and 2 related rhabdoviruses of fish, viral hemorrhagic septicemia virus (VHSV) and Hirame rhabdovirus (HRV), were used (Table 1). Included among the IHNV isolates was a representative of each of the 5 electropherotypes described by
Hsu et al. (1986). Virus stocks of ca $5 \times 10^{8} \mathrm{PFU} \mathrm{ml} \mathrm{m}^{-1}$ were prepared by inoculating CHSE-214 cells at $15^{\circ} \mathrm{C}$. Aliquots were stored at $-70^{\circ} \mathrm{C}$. Virus titers were determined by the plaque assay method using EPC cells pretreated with polyethylene glycol (Batts \& Winton 1989).

RNA extraction. Two methods were used to extract RNA from infected and control cell cultures. For selectively recovering $m$ RNA, the Fast Track (Invitrogen, San Diego, CA, USA) kit was used according to the manufacturer's instructions. Two $150 \mathrm{~cm}^{2}$ flasks of CHSE-214 cells were inoculated at a multiplicity of infection (MOI) of 10 plaque-forming units (PFU) per cell. After $1 \mathrm{~h}$, to allow for virus attachment and penetration, actinomycin $D\left(01, \mathrm{gg} \mathrm{m}^{-1}\right)$ was added to inhibit host cell transcription. The cultures were incubated at $15^{\circ} \mathrm{C}$ and harvested after $24 \mathrm{~h}$.

Total RNA was extracted using RNAzol B (Cinna/ Biotecx, Houston, TX, USA) according to the manufacturer's instructions. For all assays, cells were seeded in 8 -well cell culture plates $\left(8.6 \mathrm{~cm}^{2}\right.$ per well $)$ at a density of $5 \times 10^{6}$ cells per well. A $100 \mu$ viral inoculum was applied to drained monolayers, adsorbed for $1 \mathrm{~h}$, and fresh medium added. The cultures were incubated at $15^{\circ} \mathrm{C}$ for selected intervals, after which cells were digested for 5 to $10 \mathrm{~min}$ at room temperature (RT) by addition of $1 \mathrm{ml}$ RNAzol B. The solution was triturated, placed in a $1.5 \mathrm{ml}$ microcentrifuge tube with chloroform, and chilled on ice for $5 \mathrm{~min}$. The aqueous phase was separated by centrifugation at $12000 \times g$ for

Table 1. Six isolates of IHNV and 2 other rhabdoviruses of fish used in this study

\begin{tabular}{|c|c|c|c|}
\hline Isolate & Type $e^{a}$ & Geographic origin & Original host \\
\hline \multicolumn{4}{|l|}{ IHNV } \\
\hline $\mathrm{RB}$ & 1 & $\begin{array}{l}\text { Round Butte Hatchery } \\
\text { Deschutes River, OR, USA }\end{array}$ & Summer steelhead Oncorhynchus mykiss \\
\hline LWS & 2 & $\begin{array}{l}\text { Little White Salmon Hatchery } \\
\text { Cook, WA, USA }\end{array}$ & Spring chinook salmon $O$. tshawytscha \\
\hline SRCV & 3 & $\begin{array}{l}\text { Nimbus Hatchery } \\
\text { Sacramento River, CA, USA }\end{array}$ & Chinook salmon $O$. tshawytscha \\
\hline COL & 4 & $\begin{array}{l}\text { Coleman National Fish Hatchery } \\
\text { Sacramento River, CA, USA }\end{array}$ & Spring chinook salmon $O$. tshawytscha \\
\hline $\mathrm{CR}$ & 5 & Cedar River, WA, USA & Sockeye salmon O. nerka \\
\hline WRAC & $n t^{b}$ & $\begin{array}{l}\text { Western Regional Aquaculture } \\
\text { Consortium, Hagerman, ID, USA }\end{array}$ & Rainbow trout 0 . mykiss \\
\hline \multicolumn{4}{|l|}{ Other } \\
\hline $\begin{array}{l}\text { HRV } \\
\text { (Hirame Rhabdovirus) }\end{array}$ & - & $\begin{array}{l}\text { Hyogo Prefectural Experiment Station, } \\
\text { Hyogo, Japan }\end{array}$ & Hirame flatfish Paralichthys olivaceous \\
\hline $\begin{array}{l}\text { VHSV } \\
\text { (Viral Hemorrhagic } \\
\text { Septicemia Virus) }\end{array}$ & - & $\begin{array}{l}\text { Makah National Fish Hatchery, } \\
\text { Neah Bay, WA, USA }\end{array}$ & Fall chinook salmon $O$. tshawytscha \\
\hline
\end{tabular}


15 min at $4^{\circ} \mathrm{C}$, and the RNA precipitated with isopropyl alcohol. The mixture was centrifuged and the pelleted RNA washed with $80 \%$ ethanol and dried in a Speed Vac vacuum drier (Savant, Farmingdale, NY, USA). The RNA was stored dry or in water for short periods at $-70^{\circ} \mathrm{C}$, or in $0.3 \mathrm{M}$ sodium acetate in absolute ethanol for long periods. When stored dry, best results were obtained when the sample was resuspended in $125 \mu \mathrm{l}$ of $\mathrm{dH}_{2} \mathrm{O}$ and heated for 15 to $20 \mathrm{~min}$ at $65^{\circ} \mathrm{C}$.

Application of RNA to nitrocellulose. In the Northern blot, messenger RNA was separated by formaldehyde-denaturing agarose gel electrophoresis and transferred to $0.2 \mu \mathrm{m}$ nitrocellulose membranes (BA83; Schleicher and Schuell, Keene, NH, USA) using standard methods (Maniatis et al. 1982). For dot blot analysis, serial dilutions $\left(\log _{5}\right.$ or $\left.\log _{10}\right)$ of RNA were made in $20 \times \mathrm{SSC}$ buffer $(3 \mathrm{M}$ sodium chloride, $0.3 \mathrm{M}$ sodium citrate, $\mathrm{pH}$ 7.0) and applied to nitrocellulose membranes using a vacuum blotting device (BioRad, Richmond, CA, USA). Membranes were air-dried and baked under vacuum for $1 \mathrm{~h}$ at $80^{\circ} \mathrm{C}$.

Preparation of the oligonucleotide probe. The optimal 30-base sequence for a probe designed to hybridize to the messenger RNA of the nucleocapsid (N) gene was chosen using the Big Probe software package (Dubnick et al. 1988) and the published $\mathrm{N}$ gene sequence of the Round Butte Hatchery isolate of IHNV (Gilmore \& Leong 1988). The site selected was near the middle of the mRNA molecule, from nucleotides 427 to 456 (sense orientation) of the open reading frame. The DNA probe constructed was complementary to this region, had the antisense sequence $5^{\prime}$-CTT GTT TTG GCA GTA TGT GGC CAT CTT GTC-3', a GC:AT ratio of $47 \%$, and a predicted $T_{m}$ of $65^{\circ} \mathrm{C}$. The probe was synthesized on a DNA synthesizer (Applied Biosystems, Foster City, CA, USA) and gel-purified by the method of Ellington (1989) before labeling.

Biotin labeling of the $3^{\prime}$ end of the oligonucleotide was performed using terminal deoxynucleotidyl transferase and biotin-14 ATP nucleotides in cacodylate reaction buffer (BRL, Gaithersburg, MD, USA). One microgram of dried oligonucleotide was resuspended in $40 \mu \mathrm{l}$ of reaction buffer, $1 \mu \mathrm{l}$ of enzyme, and $10 \mu \mathrm{l}$ of biotin-14 ATP. The reaction proceeded to completion in $4 \mathrm{~h}$ at $37^{\circ} \mathrm{C}$ (Kumar et al. 1988). Unreacted nucleotides were separated on a spin column (Select $B ; 5^{\prime}-3^{\prime}$ Inc., West Chester, PA, USA). The biotinylated probe was added immediately to $10 \mathrm{ml}$ prehybridization buffer at a concentration of $100 \mathrm{ng} \mathrm{ml}^{-1}$ and stored at $-20^{\circ} \mathrm{C}$. Prehybridization buffer was $10 \times$ Denhardt's solution ( $1 \times$ Denhardt's is $0.1 \%$ each of bovine serum albumin, polyvinylpyrrolidone 360 , and Ficoll 400 ), $2 \times$ SSC, $1 \%$ sodium dodecyl sulfate (SDS), and $0.1 \mathrm{mg} \mathrm{ml}^{-1}$ sonicated salmon sperm DNA (Sigma, St Louis, MO, USA). In our hands, the solution containing the biotinylated probe could be reused at least twice before being discarded.

Labeling of the probe with ${ }^{32} \mathrm{P}$ was done using a $5^{\prime}$ end labeling system (New England Nuclear, Wilmington, DE, USA). Dried oligonucleotide $(0.5 \mu \mathrm{g})$ was

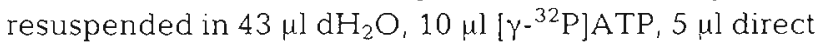
phosphorylation buffer, and $2 \mu$ polynucleotide kinase. The reaction continued $40 \mathrm{~min}$ at $37^{\circ} \mathrm{C}$. Unreacted nucleotides were separated on a spin column (Select $D$, $5^{\prime}-3^{\prime}$ Inc). The radiolabeled probe was immediately added to $10 \mathrm{ml}$ of prehybridization buffer to make the hybridization solution and stored at $-20^{\circ} \mathrm{C}$.

Prehybridization and hybridization. Nitrocellulose membranes were placed in heat-sealable hybridization pouches (BRL) with prehybridization buffer. Prehybridization was performed in a $50^{\circ} \mathrm{C}$ water bath for at least $2 \mathrm{~h}$.

The prehybridization buffer was replaced with hybridization solution (prehybridization buffer containing $100 \mathrm{ng} \mathrm{ml}^{-1}$ probe) at $0.5 \mathrm{ml}$ per $10 \mathrm{~cm}^{2}$ membrane, and reacted for 2 to $24 \mathrm{~h}$ at $50^{\circ} \mathrm{C}$. The hybridization solution could be stored at $-20^{\circ} \mathrm{C}$ for reuse.

Membranes were rinsed briefly and washed in 3 changes of buffer ( $2 \times \mathrm{SSC}, 0.1 \% \mathrm{SDS})$ for $15 \mathrm{~min}$ at $\mathrm{RT}$ and once for $15 \mathrm{~min}$ at $50^{\circ} \mathrm{C}$.

Color development of biotinylated probe. For Northern and dot blot analysis using the biotin-labeled probe, membranes were incubated in $0.1 \mu \mathrm{g} \mathrm{ml}^{-1}$ streptavidin/alkaline phosphatase conjugate (BRL) in Buffer A $(0.1 \mathrm{M}$ Tris $/ \mathrm{HCl} \mathrm{pH} 7.5,0.1 \mathrm{M} \mathrm{NaCl}, 2 \mathrm{mM} \mathrm{MgCl}$, $0.05 \%$ Triton X-100; Riley et al. 1986) for 30 min at RT with agitation. Membranes were rinsed briefly and washed twice for 7 min at RT in Buffer $\mathrm{A}$, then twice for 7 min at $\mathrm{RT}$ in Buffer $\mathrm{B}(0.1 \mathrm{M}$ Tris/ $\mathrm{HCl}$ pH $9.5,0.1 \mathrm{M}$ $\mathrm{NaCl}, 50 \mathrm{mM} \mathrm{MgCl} \mathrm{M}_{2}$ ). Color development was allowed to proceed in the dark $15 \mathrm{~min}$ to overnight using a color development solution (BioRad) containing nitro blue tetrazolium (NBT) and 5-bromo-4-chloro-3-indolyl phosphate (BCIP). The membranes were washed $10 \mathrm{~min}$ in deionized water and air-dried for storage.

Hybridization kinetics. The kinetics of the hybridization reaction were studied to establish the minimum incubation time required for an efficient reaction. Dots containing ca $0.1 \mu \mathrm{g}$ purified $\mathrm{N}$ gene mRNA or control mRNA were made on a nitrocellulose membrane using a vacuum blotting device. Individual dots were cut from the membrane and reacted with the ${ }^{32} \mathrm{P}$ labeled probe for 5, 15, 45, $90 \mathrm{~min}$, and $16 \mathrm{~h}$. Immediately after each hybridization period, a pair of control and viral mRNA dots were removed and washed 3 times for $15 \mathrm{~min}$ at RT and once for $15 \mathrm{~min}$ at $50^{\circ} \mathrm{C}$ in $2 \times \mathrm{SSC}$ containing $0.1 \%$ SDS. The dots were air-dried and individually placed in scintillation vials with $5 \mathrm{ml}$ scintillation cocktail. A Beckman LS 1801 liquid scintillation counter was used to determine counts per minute 
(CPM) from the probe remaining bound to the dots. Control dots established a background level to which the viral mRNA dots could be compared. Statistical analysis of the counting accuracy was performed by the machine and CPM data were reported with $95 \%$ confidence intervals.

Probe specificity and sensitivity. Purified IHNV mRNA and a 0.24 to 9.5 kilobase RNA size standard (BRL) were separated by denaturing gel electrophoresis and stained with ethidium bromide. The expected molecular weight of the $\mathrm{N}$ gene mRNA was calculated using the published length of the molecule (Gilmore \& Leong 1988), adding 150 bases for a poly-A tail. The expected position of the $\mathrm{N}$ gene mRNA in the gel was determined by comparison with the RNA size standard. Specificity of the probe was demonstrated by visualization of a single band at the same position following Northern blot transfer

The sensitivity of the biotinylated probe under optimal conditions was measured by hybridizing the probe to dots containing serial dilutions of purified $\mathrm{N}$ gene mRNA. The quantity of $N$ gene mRNA applied to each dot was estimated by comparing the intensity of the ethidium bromide stained band of IHNV $N$ gene mRNA used to make the dots with the intensity of the size standard bands in the gel, each containing $1 \mu \mathrm{g}$ of RNA. The approximate amount of $N$ gene mRNA visualized at the serial dilution end-point was calculated.

Time of earliest detection of $\mathbf{N}$ gene mRNA. Duplicate wells of CHSE-214 cells were inoculated with the Round Butte isolate of IHNV at a MOI of 10 PFU per cell. Total RNA was extracted from infected and control cells by the RNAzol B method at $0,3,6,9,12$, and $24 \mathrm{~h}$ after inoculation. For each time interval, $\log _{5}$ serial dilutions of the RNA were made and applied as dots to nitrocellulose. The blot was hybridized with the biotinylated probe, washed, and developed.

Reaction of the probe with eight rhabdovirus isolates. Duplicate wells of CHSE-214 cells were inoculated at a $\mathrm{MOI}$ of 10 to $100 \mathrm{PFU}$ cell ${ }^{-1}$ with the 8 rhabdovirus isolates listed in Table 1 . Infected and control cells were incubated at $15^{\circ} \mathrm{C}$. At 18 to $20 \mathrm{~h}$ postinfection the RNA was harvested with RNAzol B, applied as dots to nitrocellulose, and reacted with the probe.

Comparison of cell lines. The CHSE-214, $\mathrm{CHH}-1$, and EPC cell lines were compared for their ability to produce extractable $\mathrm{N}$ gene mRNA during early phases of IHNV infection. The Round Butte isolate of IHNV was added at a MOI of 10 PFU cell ${ }^{-1}$ to duplicate wells of each cell type. Infected and control cells were incubated at $15^{\circ} \mathrm{C}$ for 18 to $20 \mathrm{~h}$ before harvesting with RNAzol B. For each cell type, $\log _{5}$ serial dilutions of the RNA were made and applied as dots to nitrocellulose.
Rate of $\mathrm{N}$ gene mRNA production at different MOI. The time required for the appearance of detectable $\mathrm{N}$ gene mRNA in cell culture was determined for cells infected at different MOI. Replicate wells of CHH-1 cells were inoculated with the Round Butte isolate of IHNV at a MOI of 2,0.02, and 0.0002. Every day for $7 \mathrm{~d}$, total RNA was extracted by the RNAzol B method from control cells and cells infected at each MOI. The extracted RNA was stored dry at $-80^{\circ} \mathrm{C}$ until all plates had been harvested.

\section{RESULTS}

\section{Probe reaction kinetics}

Individual dots containing purified IHNV $\mathrm{N}$ gene mRNA and control dots containing mRNA extracted from uninfected cells were removed at specific times following hybridization with the probe. The number of ${ }^{32} \mathrm{P}$ labeled probe molecules bound to the $\mathrm{N}$ gene target mRNA showed a rapid increase over the first 1.5 to $2 \mathrm{~h}$ (Fig. 1). The hybridization reaction was essentially complete at $2 \mathrm{~h}$, and counts at $16 \mathrm{~h}$ were only slightly higher than counts at $1.5 \mathrm{~h}$. Control dots removed from the reaction at the same time intervals showed only a slight increase in counts over $16 \mathrm{~h}$.

\section{Probe specificity and sensitivity}

In the Northern blot assays using purified IHNV mRNA subjected to denaturing gel electrophoresis, passive transfer to nitrocellulose, and hybridization

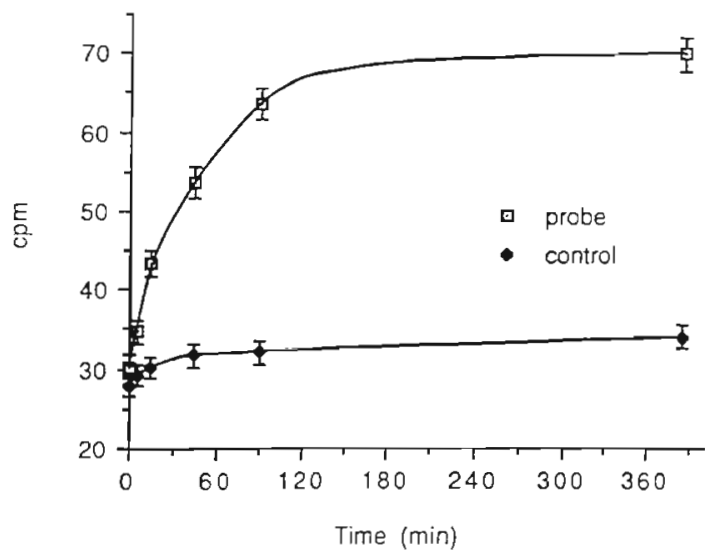

Fig. 1 Kinetics of the hybridization reaction between a radiolabeled oligonucleotide probe and purified mRNA extracted from cells infected with the Round Butte isolcte of IHNV. Radioactive probe bound rapidly to the target $v$ gene mRNA in the first $2 \mathrm{~h}$ of the hybridization reaction, compared to controls of uninfected cell extract. Counts per minute (cpm) were recorded on a Beckman LS 1801 scintillation counter. Error bars represent $95 \%$ confidence intervals 


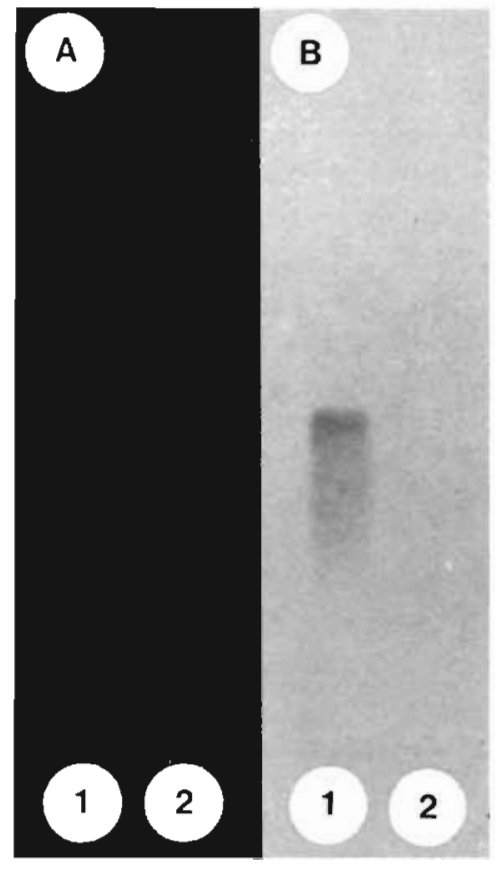

Fig. 2. Formaldehyde denaturing gel electrophoresis of purified IHNV mRNA. (A) RNA size standard (lane 1) and purified IHNV mRNA (lane 2) stained with ethidium bromide and viewed under ultraviolet light. (B) Northern blot from the same gel after electrophoresis, passive transfer to nitrocellulose, and hybridization with a biotinylated oligonucleotide probe specific for $\mathrm{N}$ gene mRNA of IHNV Purified mRNA from IHNV infected cells is in lane 1 and mRNA from uninfected cells is in lane 2 . The single band recognized by the probe in lane 1 of (B) corresponds by position to a light band in lane 2 of (A) that is of the approximate size reported for the $N$ gene mRNA (Kurath \& Leong 1985)

with the biotinylated probe, a single band of RNA was recognized by the probe (Fig. 2). This band corresponded to the position of a mRNA band of ca 1500 nucleotides present in an ethidium bromide stained sample of IHNV mRNA from the same gel. Other IHNV mRNAs, and host cell RNA not removed by the Fast Track procedure, were visible in the ethidium bromide stained portion of the gel but were not recognized by the probe. These results indicate that the probe was highly specific for the $\mathrm{N}$ gene mRNA molecule.

The sensitivity of the probe was determined by estimation of the end point of a $\log _{10}$ serial dilution dot blot of purified $N$ gene mRNA. When compared to controls, a positive signal was observed in dots containing ca $1 \mathrm{pg}$ of target sequence.

\section{Earliest detection of $\mathbf{N}$ gene mRNA in cell culture}

By dot blot hybridization analysis, Round Butte IHNV $N$ gene mRNA was detected in cell culture extracts ca 6 to $9 \mathrm{~h}$ after initial infection (MOI $=10$ ). The accumulation of $\mathrm{N}$ gene mRNA reached a maximum by $12 \mathrm{~h}$, and production was sustained through $24 \mathrm{~h}$. The probe did not cross-react with RNA extracted from uninfected, control cells (data not shown).

\section{Comparison of isolates}

Six IHNV isolates and 2 other rhabdoviruses of fish (Table 1) were tested for hybridization with the probe. The 6 isolates of IHNV, representing all 5 electropherotypes of IHNV described by Hsu et al. (1986), gave positive reactions following dot blot hybridization (Fig. 3). These types were originally isolated from a broad geographic and host range, and are distinguished primarily by differences in the molecular weight of the $\mathrm{N}$ protein. The uninfected control cell extract, and the viruses HRV and VHSV were not recognized by the probe.

\section{Evaluation of cell lines}

Cultures of CHSE-214, CHH-1, and EPC cells were infected with the Round Butte isolate of IHNV and harvested by the RNAzol B method at 18 to $20 \mathrm{~h}$ after infection. Dot blot analysis of serially diluted RNA revealed that all 3 cell lines were competent to produce adequate amounts of $\mathrm{N}$ gene mRNA under these conditions. While the CHH-1 cells produced slightly darker spots at each dilution, suggesting more $\mathrm{N}$ gene mRNA was present, the CHSE-214 and EPC cell lines produced spots of approximately equal intensity. The difference among the lines was judged to be less than 5 -fold.

Fig. 3. Dot blot analysis of RNA extracted from cells infected with isolates of IHNV, HRV, and VHSV, listed in Table 1. Isolates were grown for $18-20 \mathrm{~h}$ in CHSE-214 cells, and the RNA extracted by the RNAzol B method, applied to nitrocellulose, and hybridized with the biotinylated IHNV $N$ gene mRNA probe. Isolates are: RB, lane 1; LWS, lane 2; SRCV, lane 3; COL, lane 4; $C R$, lane 5; WRAC, lane 6; HRV, lane 7; VHSV, lane 8; and uninfected cell extract, lane 9

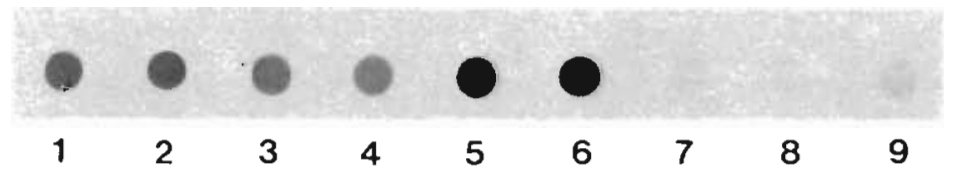




\section{Rate of $\mathrm{N}$ gene mRNA production at different MOI}

Inoculation of cell cultures at the highest MOI (MOI $=2$ ) resulted in early and sustained detection of $\mathrm{N}$ gene mRNA (Fig. 4). Inoculation of cells at intermediate levels of infection (MOI $=0.02$ ) produced detectable mRNA on the second day, while low MOI (MOI = 0.0002 ) produced detectable mRNA on the fourth day. Cultures infected at low $\mathrm{MOI}$ required $5 \mathrm{~d}$ for a strongly positive hybridization signal. Extracts from cell cultures infected at all MOI provided clearly detectable RNA after $5 \mathrm{~d}$ incubation.

\section{DISCUSSION}

Viruses are difficult to detect directly unless present in large quantities. For this reason the ELISA, FAT, and immunoblot rapid assays for IHNV usually rely on initial amplification of viral antigens in cell culture (Dixon \& Hill 1984, McAllister \& Schill 1986, Way \& Dixon 1988, LaPatra et al. 1989). The DNA probe assay reported here also used amplification of IHNV nucleic acids in cell culture, analogous to amplification of antigens for serological tests. However, viral mRNA appears earlier in infected cells than its corresponding protein and can be rapidly extracted for analysis. In addition, antibodies, particularly monoclonal antibodies, are expensive and time-consuming to develop, while DNA oligonucleotide probes can be inexpensively synthesized.

Because the sequence of the nucleoprotein mRNA of the Round Butte isolate of IHNV has been determined

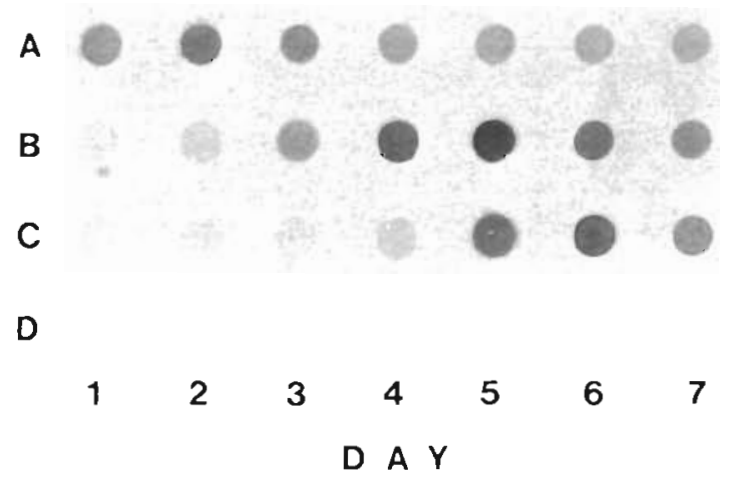

Fig. 4. Dot blot analysis of RNA harvested at each of 7 days from $\mathrm{CHH}-1$ cells inoculated with the Round Butte isolate of IHN virus at selected multiplicities of infection. A high level of $\mathrm{N}$ gene mRNA could be extracted from cells infected at $\mathrm{MOI}$ of 2.0 after $1 \mathrm{~d}$ (row A). This mRNA could be detected over the entire $7 \mathrm{~d}$ period. Extracts of RNA from cell cultures infected at intermediate MOI (0.02) are shown in row B. Cultures infected at low $\mathrm{MOL}(0.0002)$ required 4 to $5 \mathrm{~d}$ incubation before sufficient mRNA was present to provide a positive reaction (row C). Uninfected extracts from each day of incubation are shown in row $D$
(Gilmore \& Leong 1988), an oligonucleotide probe was synthesized that hybridized with this molecule, avoiding the expense and inconvenience of producing the probe by conventional molecular cloning techniques. Oligonucleotide probes can be prepared in a few days. are easier to label than cloned probes, and give lower background (Coghlan et al. 1985). These probes can be ordered already biotinylated, or in a gel purified form ready for labeling. Several hundred samples could be tested at a cost of about US $\$ 0.25$ of labeled probe per sample.

In the course of rhabdovirus replication, the first events to take place after entry and uncoating of the virus involve transcription of $(+)$ sense mRNA from the (-) sense genome (Rose \& Schubert 1987). Six IHNV genes are transcribed into mRNA by a viral RNA-dependent polymerase (Kurath \& Leong 1985). Because of the genome organization of rhabdoviruses and sequential mRNA transcription, the mRNA coding for the nucleocapsid protein ( $N$ gene mRNA) is transcribed earliest and in the greatest abundance (Rose \& Schubert 1987). For one of the best studied rhabdoviruses, vesicular stomatitis virus (VSV), the molar ratio of $\mathrm{N}$ gene mRNA from transcription versus genomic RNA from replication during the growth cycle within a cell is $100: 1$, the greatest of the mRNA species (Villarreal et al. 1976). Consequently, of the 6 IHNV mRNA species, the $\mathrm{N}$ gene mRNA provides the greatest target amplification in the shortest time and was therefore selected as the best target for a DNA probe.

Because the probe was synthesized from the published sequence of the Round Butte isolate, we anticipated that mRNA extracted from this homologous isolate should produce the strongest hybridization signal. However, results from the dot blot analysis of 6 IHNV isolates suggested that isolates producing higher titers (WRAC and CR) produced the darkest dots. These differences in dot intensity could also be due to differences in the replication rate of the isolates, or in the titer of the stock virus used to infect the cultures. With the reaction conditions used, a reduction in the affinity of the probe for the target due to incomplete sequence homology was difficult to detect. Oligonucleotide probes can detect single base substitutions in the target sequence if isolates are compared under stringent conditions (Tenover 1988). To determine the homology of the isolates over the 30 nucleotide target sequence, the isolates could be compared at more stringent hybridization conditions using equal amounts of target mRNA.

The probe was able to detect and identify mRNA extracted from cell cultures infected at high, medium, and low MOI and incubated for 4 to $5 \mathrm{~d}$ post-inoculation. The levels selected reflect a range of titers typically encountered in infected fish. Although mRNA produced in cells infected with high levels of virus 
could be detected after only a few hours, low levels of infection (ca 1000 virus particles in the inoculum) required $5 \mathrm{~d}$ for sufficient $\mathrm{mRNA}$ to be produced to yield a positive identification. This effect was probably due to the ratio of cells actively producing viral mRNA at any given time. When infected at a high MOI, all cells were in the same stage of infection resulting in maximum production of target $m$ RNA and in optimal detection. In cultures infected at a low MOI, RNA extracted from uninfected cells diluted the small amount of target sequence present, while at the end of the infection cycle, the amount of viral mRNA began to decline. Although the intensity of the dots decreased slightly after $2 \mathrm{~d}$, cultures infected at high MOI continued to yield detectable mRNA for at least. $7 \mathrm{~d}$. This indicates that when testing samples of unknown virus content, highly infected samples will still produce a positive signal after waiting the necessary time to amplify low levels of virus. Highly infected cultures produced detectable quantities of $\mathrm{N}$ gene mRNA well before the appearance of cytopathic effect (CPE), while cultures infected at lower MOI produced small foci of $\mathrm{CPE}$ in the cell monolayer before MRNA was detectable.

A nonradioactive label for the probe was considered important. The disadvantages of using radiolabeled probes include a requirement for trained technicians and permits for handling radioactive materials, as well as concerns for safety and expense. Radiolabeled probes are inherently unstable; probes labeled with ${ }^{32} \mathrm{P}$ have a half-life of $14 \mathrm{~d},{ }^{125}$ I labeled probes, $60 \mathrm{~d}$ (Tenover 1988), while biotinylated probes are stable for long periods of time (Brigati et al. 1983). The biotin label does not interfere with the ability of the probe to hybridize with the target nucleic acid (Maitland et al. 1987) and several workers have reported comparable sensitivity of biotinylated and radiolabeled probes (Chan et al. 1985, Habili et al. 1987, Quibriac et al. 1989).

The alkaline phosphatase colorimetric reaction in the assay was essentially complete after $15 \mathrm{~min}$, with the color intensity increasing only slightly at $1 \mathrm{~h}$. Nonspecific background was eliminated by optimizing the concentration of the streptavidin-alkaline phosphatase conjugate, including Denhardt's solution in the prehybridization and hybridization buffers, incubating the color development step in the dark, and limiting the incubation time to under $1 \mathrm{~h}$. Blots left in developer overnight had nonspecific background both on the membrane and controls, probably due to binding of the enzyme conjugate. No filter blocking was required before application of the enzyme conjugate. The enzyme conjugate solution was used at low concentration and could be reused at least 5 times without detectable loss of activity, making the cost per sample extremely low. The use of a commercial enzyme substrate solution was simple, and provided more consistent and satisfactory results than using raw reagents.

The probe did not react with HRV and VHSV, 2 closely related rhabdoviruses of fish belonging to the Lyssavirus genus. In some situations, however, it would be valuable that a test be able to determine whether a sample contained any of several fish viruses. A DNA probe designed to identify all rhabdoviruses of fish could be combined with a second test using more specific probes. Given sufficient nucleotide sequence information, or by judicious selection of the target sequence and hybridization conditions, probes could be designed to detect all rhabdoviruses of fish, one particular virus, or possibly individual isolates.

DNA probe technology is still in relatively early stages of development and application (Yolken 1988), and will soon provide a low cost, rapid, and automated diagnostic tool for many important infectious diseases (Landegren et al. 1988). The polymerase chain reaction (PCR) can amplify a specific region of nucleic acid at least one million-fold in a few hours (Saiki et al. 1985), with the product detected by a DNA probe. Initial application of this technique for amplification of an IHNV N gene sequence has been reported (Arakawa et al. 1990).

Biotinylated oligonucleotide probes are well suited for in situ hybridization using tissue sections from infected animals (Coghlan et al. 1985, Cubie \& Norval 1988). This technique, in combination with the PCR, has significant application for research into the carrier state of IHNV, as it has the potential to detect nucleic acids of viruses in a latent state (Maitland et al. 1987).

Acknowledgements. We thank Pete Lockhart for technical assistance and synthesis of the DNA oligonucleotide used in this study. This work was supported by the Western Regional Aquaculture Consortium under U.S. Department of Agriculture Grant No. 87-CRSR-2-3219.

\section{LITERATURE CITED}

Amos, K. H. (ed.) (1985). Procedures for the detection and identification of certain fish pathogens, 3rd edn. Fish Health Section, American Fisheries Society. Corvallis, Oregon. (Available from AFS, Bethesda, Maryland)

Arakawa, C. K., Deering, R. E., Higman, K. H., Oshima, K. H., O'Hara, P. J., Winton, J. R. (1990). Polymerase chain reaction (PCR) amplification of a nucleoprotein gene sequence of infectious hematopoietic necrosis virus. Dis. aquat. Org. 8: $165-170$

Batts, W. N., Winton, J. R. (1989). Enhanced detection of infectious hematopoietic necrosis virus and other fish viruses by pretreatment of cell monolayers with polyethylene glycol. J. aquat. Anim. Health 1: 284-290

Bovo, G., Giorgetti, G., Jorgensen, P. E. V., Olsen, N. J. (1987). 
Infectious haematopoietic necrosis virus: first detection in Italy. Bull. Eur Ass. Fish Pathol. 7(5): 124

Brigati, D. J., Myerson, D., Leary, J. J., Spalholz, B., Travis, S. Z., Fong, C. K. Y., Hsiung, G. D., Ward, D. C. (1983). Detection of viral genomes in cultured cells and paraffinembedded tissue sections using biotin-labeled hybridization probes. Virology 126: 32-50

Bryan, R. N., Ruth, J. L., Smith, R. D., Le Bon, J. M. (1986) Diagnosis of clinical samples with synthetic oligonucleotide hybridization probes. In: Leive, L. (ed.) Microbiology 1986. American Society for Microbiology, Washington, D.C., p. $113-116$

Chan, V. T., Fleming, F. A., McGee, J. O. (1985). Detection of subpicogram quantities of specific DNA sequences on blot hybridization with biotinylated probes. Nuc. Acids Res. 13: 8083-8091

Chen, S. N., Kou, G. H., Hedrick, R. P., Fryer, J. L. (1985). The occurrence of viral infections of fish in Taiwan. In: Ellis, A. E. (ed.) Fish and shell tish pathology. Academic Press, New York, p. 313-319

Coghlan, J. P., Aldred, P., Haralambidis, J., Niall, H. D., Penschow, J. D., Tregear, G. W. (1985). Hybridization histochemistry. Analyt. Biochem. 149: 1-28

Cubie, H. A., Norval, M. (1988). Synthetic oligonucleotide probes for the detection of human papilloma virus by in situ hybridisation. J. Virol. Meth. 20: 239-249

Dixon, P. F., Hill, B. J. (1984). Rapid detection of fish rhabdoviruses by the enzyme-linked immunosorbent assay (ELISA). Aquaculture 42:1-12

Dubnick, M., Lewis, L. K., Mount, D. W. (1988). BIG PROBE: a computer program that predicts the sequence of long oligonucleotide probes with high reliability. Nuc. Acids Res. 16: 1703-1714

Ellington, A. (1989). Synthesis and purification of oligonucleotides. In: Ausubel, F. M., Brent, R., Kingston, R. E., Moore, D. D., Seidman, J. G., Smith, J. A., Struhl, K. (eds.) Current protocols in molecular biology, Vol 1. Green Publishing Associates and Wiley-Interscience, New York, p. $2.12 .1-2.12 .5$

Fijan, N., Sulimanović, D., Bearzotti, M., Muzinić, D., Zwillenberg, L. O., Chilmonczyk, S., Vautherot, J. F., de Kinkelin, P. (1983). Some properties of the epithelioma papulosum cyprini (EPC) cell line from carp Cyprinus carpio. Ann. Virol. (Inst. Pasteur). 134: 207-220

Gilmore, R. D., Leong, J. C. (1988). The nucleocapsid gene of infectious hematopoietic necrosis virus, a fish rhabdovirus. Virology 167: 644-648

Grischkowsky, R. S., Amend, D. F. (1976). Infectious hematopoietic necrosis virus: prevalence in certain Alaskan sockeye salmon, Oncorhynchus nerka. J. Fish. Res. Bd Can. 33: 186-188

Habili, N., Mclnnes, J. L., Symons, R. H. (1987). Nonradioactive, photobiotin-labelled DNA probes for the routine diagnosis of barley yellow dwarf virus. J. Virol. Meth. 16: 225-237

Hattenberger-Baudouy, A. M., Danton, M., Merle, G., Torchy, C. de Kinkelin, P. (1989). Serological evidence of infectious hematopoietic necrosis in rainbow trout from a French outbreak of disease. J. aquat. Anim. Health. 1: $126-134$

Hsu Y L., Engelking, H. M., Leong, J. C. (1986). Occurrence of different types of infectious hematopoietic necrosis virus in fish. Appl. environ. Microbiol. 52: 1353-1361

Hsu, Y L., Leong, J. C. (1985). A comparison of detection methods for infectious haematopoietic necrosis virus. J. Fish Dis. 8: 1-12

Kumar, A., Tchen, P., Roullet, F., Cohen, J. (1988). Non- radioactive labeling of synthetic oligonucleotide probes with terminal deoxynucleotidyl transferase. Analyt. Biochem. 169: 376-382

Kurath, G., Leong, J. C. (1985). Characterization of infectious hematopoietic necrosis virus mRNA species reveals a nonvirion rhabdovirus protein. J. Virol. 53: 462-468

Kurstak, E., Tijssen, P., Kurstak, C., Morisset, R. (1986) Enzyme immunoassays and related procedures in diagnostic medical virology. Bull. World Health Org. 64: 465-479

Landegren, U., Kaiser, R., Caskey, C. T., Hood, L. (1988). DNA diagnostics - molecular techniques and automation. Science 242: 229-237

Lannan, C. N., Winton, J. R., Fryer, J. L. (1984). Fish cell lines: establishment and characterization of nine cell lines from salmonids. In Vitro 20:671-676

LaPatra, S. E., Roberti, K. A., Rohovec, J. S., Fryer, J. L. (1989) Fluorescent antibody test for the rapid diagnosis of infectious hematopoietic necrosis. J. aquat. Anim. Health. 1: $29-36$

McAllister, P. E., Schill, W B. (1986). Immunoblot assay: a rapid and sensitive method for identification of salmonid fish viruses. J. Wildl. Dis. 22: 468-474

Maitland, N. J., Cox, M. F., Lynas, C., Prime, S., Crane, I., Scully, C. (1987). Nucleic acid probes in the study of latent viral disease. J. Oral Pathol. 16: 199-211

Maniatis, T., Fritsch, E. F. Sambrook, J. (1982). Molecular cloning (a laboratory manual). Cold Spring Harbor Laboratory, Cold Spring Harbor, New York

Quibriac, M., Petitjean, J., Thiers, V., Tiollais, P., Brechot, C. Freymuth, F. (1989). Comparison of a non-radioactive hybridization assay for detection of hepatitis B virus DNA with the radioactive method. Mol. Cell. Probes 3: 209-212

Richman, D. D., Wahl, G. M. (1986). Nucleic acid probes to detect viral diseases. In: Notkins, A. B., Oldstone, M. B. A. (eds.) Concepts in viral pathogenesis II. Springer-Verlag, New York, p. 301-309

Riley, L. K., Marshall, M. E., Coleman, M. S. (1986). A method for biotinylating oligonucleotide probes for use in molecular hybridizations. DNA 5: 333-337

Rose, J., Schubert, M. (1987). Rhabdovirus genomes and their products. In: Wagner, R. R. (ed.) The rhabdoviruses. Plenum Press, New York, p. 129-166

Saiki, R. K., Scharf, S., Faloona, F., Mullis, K. B., Horn, G. T., Erlich, H. A., Arnheim, N. (1985). Enzymatic amplification of beta-globin genomic secruences and restriction site analysis for diagnosis of sickle cell anemia. Science 230: $1350-1353$

Sano, T., Nishimura, T., Okamoto, N., Yamakazi, T., Hanada, H., Watanabe, Y. (1977). Studies on viral diseases of Japanese fishes. VI. Infectious hematopoietic necrosis (IHN) of salmonids in the mainland of Japan. J. Tokyo Univ. Fish. 63: 81-85

Tenover, F. C. (1988). Diagnostic deoxyribonucleic acid probes for infectious diseases. Clin. Microbiol. Rev. 1 82-101

Traxler, G. S. (1986). An epizootic of infectious hematopoietic necrosis in 2-year-old kokanee, Oncorhynchus nerka (Walbaum) at Lake Cowichan, British Columbia. J. Fish Dis. 9: $545-549$

Villarreal, L. P., Breindl, M., Holland, J. J. (1976). Determination of molar ratios of vesicular stomatitis virus induced RNA species in. BHK 21 cells. Biochemistry 15: 1663-1667

Way, K., Dixon, P. F. (1988). Rapid detection of VHS and IHN viruses by the enzyme-linked immunosorbent assay (ELISA). J. appl. [chthyol. 4: 182-189

Williams, I., Amend, D. F (1976). A natural epizootic of infectious hematopoietic virus in fry of sockeye salmon 
(Oncorhynchus nerka) at Chilko Lake, British Columbia. J. Fish. Res. Bd Can. 33: 1564-1567

Wolf, K. (1988). Fish viruses and fish viral diseases. Comstock Publishing Associates, Ithaca, New York

Responsible Subject Editor: W. Ahne, Munich, Germany
Yolken, R. H. (1988). Nucleic acids or immunoglobulins which are the molecular probes of the future? Mol. Cell. Probes 2: 87-96

Manuscript first received: July 10, 1990 Revised version accepted: February 6, 1991 